\title{
Autocrine signals promote osteoblast survival in culture
}

\author{
A Tumber, M C Meikle and P A Hill \\ Bone Biology Unit, Department of Orthodontics and Paediatric Dentistry, Guy's, King's and St Thomas' Hospital's Medical and Dental Schools, \\ Guy's Hospital, St Thomas' Street, London SE1 9RT, UK \\ (Requests for offprints should be addressed to P A Hill, Department of Orthodontics, Guy's Tower, Floor 22, Guy's Hospital, London Bridge, \\ London SE1 9RT, UK)
}

\begin{abstract}
We have studied the survival requirements of osteoblasts to test the hypothesis that osteoblasts undergo programmed cell death (PCD) or apoptosis unless they are continuously signalled by other cells not to do so. Osteoblasts survived for 6 days in culture at high cell density in the absence of other cell types, serum or exogenous proteins, but they died with the morphological features of apoptosis in these conditions at low cell density. Osteoblast survival was enhanced during the first 2 days of culture by the addition of the sulphydryl compound, cysteine to the culture medium which was converted intracellularly to the antioxidant glutathione. Catalase, an enzyme decomposing hydrogen peroxide, also protected the cells, whereas superoxide dismutase had no effect. Therefore, osteoblasts in culture are sensitive to toxic compounds derived from molecular oxygen, i.e. hydroxyl radicals or
\end{abstract}

hydrogen peroxide spontaneously generated in CMRL medium containing ascorbate and ferrous ions. Conditioned medium from high density cultures prevented osteoblast apoptosis in low density cultures, as long as antioxidants were also present. The enhancing effect of conditioned medium on osteoblast survival was prevented by neutralizing antibodies to insulin-like growth factor-I (IGF-I) and IGF-II but not by antibodies to either platelet-derived growth factor (PDGF) or basic fibroblast growth factor (bFGF). These results suggest that in addition to regulating cell growth and differentiation, IGF-I and IGF-II also function as survival factors for osteoblasts. Our data also indicate that antioxidants are required for osteoblast survival and that they enhance growth factor mediated osteoblast survival.

Journal of Endocrinology (2000) 167, 383-390

\section{Introduction}

Compared with the great effort that has been devoted to studying the control of cell proliferation, remarkably little work has been done on the control of cell survival. Yet for some vertebrate cell types at least, it is clear that signals from other cells are required for cell survival, just as they are for cell growth and proliferation (Baserga 1985). Osteoblasts and oligodendrocytes require specific growth factors such as insulin-like growth factor-I (IGF-I) and IGF-II (Barres et al. 1992, Hill et al. 1997), developing neurons require neurotrophic factors (Levi-Montalcini 1987) and myeloid cells require colony-stimulating factors (Williams et al. 1990). If deprived of their survival factors, these cells seem to activate an intrinsic death programme and kill themselves - a process called apoptosis. Because apoptosis is frequently the end-result of a temporal course of cellular events, it is sometimes referred to as programmed cell death (PCD). PCD occurs in a wide variety of cell types and is recognized to have a major impact on the development of numerous systems (Wyllie 1980, Wyllie et al. 1980). Historically, the term apoptosis refers to the characteristic morphology of cells undergoing PCD. Apoptotic cells appear shrunken, with extensive membrane blebbing and nuclear fragmentation (Wyllie et al. 1980). The end point in PCD involves the fragmentation of the cells into membrane-bound vesicles containing cellular remnants of protein and fragmented chromatin, referred to as apoptotic bodies.

It has been hypothesized that all mammalian cells except for blastomeres (Biggers et al. 1971), are programmed to kill themselves unless they are continuously signalled by other cells not to do so (Raff 1992). Such 'social' controls on cell survival would ensure that cells only survive when and where they are needed. This hypothesis is valid for lens epithelial cells and chondrocytes (Ishizaki et al. 1993, 1994). Both cells types can survive in the absence of other cell types, serum and exogenous proteins if cultured at high density, but they undergo PCD if cultured in these conditions at low cell density (Ishizaki et al. 1993, 1994). It would appear that chondrocytes are sensitive to growth factor deprivation and toxic oxygen metabolites derived from molecular oxygen, i.e. hydroxyl radicals or hydrogen peroxide, although their relative contribution to chondrocyte survival remains uncertain. Cartilage is an unusual tissue in that it contains only a single cell type and is not innervated, vascularized or penetrated by lymphatic vessels (Goss 1978, Fawcett 1986). It is possible that chondrocytes 
have adapted to their environment in some manner which has permitted them to survive under these conditions. Recent studies highlight the importance of osteoblast apoptosis in bone diseases such as glucocorticoid-induced osteoporosis and the use of agents such as bisphosphonates (Plotkin et al. 1999) and oestrogen (Gohel et al. 1999) in preventing apoptosis in osteoblasts.

In the present study, we set out to challenge this death-by-default hypothesis by focusing on bone, a tissue which comprises more than one cell type. In particular we assessed the survival requirements of osteoblasts as this cell type can be isolated from bone tissue free from contaminating cell types. Our aim was to establish whether osteoblasts can survive in a similar manner to chondrocytes and determine the survival requirements of these cells in culture.

\section{Materials and Methods}

\section{Reagents}

Terminal deoxynucleotidyl transferase, biotinylated dUTP and streptavidin fluorescein were purchased from Boehringer Mannheim GmbH, Lewes, East Sussex, UK. 3-(4,5-dimethyl-thiazol-2-yl)-2,5-diphenyl tetrazolium bromide (MTT) and all cell culture reagents were purchased from Sigma Chemical Co. (St Louis, MO, USA). The following anti-human polyclonal antibodies were purchased from R and D Systems (Abbingdon, Oxford, UK): IGF-I, IGF-II, basic fibroblast growth factor (bFGF) and platelet-derived growth factor (PDGF). $\left[{ }^{3} \mathrm{H}\right]$ cytidine was purchased from Amersham International, Little Chalfont, Buckinghamshire, UK.

\section{Preparation and characterization of osteoblasts from neonatal mouse calvaria}

Murine calvarial osteoblasts were prepared and characterized as previously described (Heath et al. 1984). Briefly, neonatal mouse calvariae were dissected free from adherent soft tissue, washed in $\mathrm{Ca}^{2+}-$ and $\mathrm{Mg}^{2+}$-free Tyrode's solution $(10 \mathrm{~min})$ and sequentially digested with $1 \mathrm{mg} / \mathrm{ml}$ trypsin $(10 \mathrm{~min}), 2 \mathrm{mg} / \mathrm{ml}$ dispase $(30 \mathrm{~min})$ and $2 \mathrm{mg} / \mathrm{ml}$ collagenase $(2 \times 30 \mathrm{~min})$. Cells released by the last two collagenase digestions were washed and grown in alpha modification of minimum essential medium ( $\alpha$ MEM) containing 10\% FBS and antibiotics for 4 days prior to use. Osteoblasts were characterized for alkaline phosphatase by incubating the cells for $45 \mathrm{~min}$ at room temperature in $0.1 \mathrm{M}$ Tris $-\mathrm{HCl}$ containing $0.1 \mathrm{mg} / \mathrm{ml}$ naphthol AS-MX phosphate and $0.6 \mathrm{mg} / \mathrm{ml}$ fast red TR salt. Intracellular accumulation of cyclic AMP in response to parathyroid hormone was measured by enzyme immunoassay (Amersham).

\section{Preparation of osteoblast conditioned medium}

Osteoblasts were cultured in 96-well tissue culture plates at $10^{5}$ cells/well and medium was removed and replaced by fresh CMRL medium every 2 days. The conditioned medium was immediately transferred to low density cultures, which were fed with conditioned medium every 2 days.

\section{Fractionation of conditioned medium by ultrafiltration}

A $1.5 \mathrm{ml}$ volume of conditioned medium from high density osteoblast cultures was poured into the filter cup of a Millipore ultrafiltration unit (molecular mass cut-off $5 \mathrm{kDa}$ ), and centrifuged at $3000 \mathrm{~g}$ for $45 \mathrm{~min}$ at room temperature. The concentrate $(1.0 \mathrm{ml})$ and filtrate $(0.5 \mathrm{ml})$ were sterilized by passage through a $0 \cdot 22 \mu \mathrm{m}$ Millipore filter and immediately transferred to low density osteoblast cultures.

\section{Osteoblast survival assays}

For survival assays, osteoblasts were plated in $100 \mu \mathrm{l}$ of CMRL-1066 medium with 1\% FCS for $2 \mathrm{~h}$ to permit adhesion of osteoblasts. Thereafter media was replaced with serum-free CMRL-1066 medium containing thymidine $\left(10^{-3} \mathrm{M}\right)$ to block cell proliferation, with or without cysteine or osteoblast conditioned medium (see below).

The human osteoblastic cell line MG63 was used in some experiments. These cells have a well characterized osteoblast phenotype and are frequently used to study the effects of cytokines and growth factors in vitro.

MTT assay Cell survival was assayed in flat-bottomed 96-well microtitre plates. Cell survival was assessed by the MTT assay, which measures mitochondrial dehydrogenase activity (Mosmann 1983). MTT was dissolved in PBS at a concentration of $5 \mathrm{mg} / \mathrm{ml}$ and sterilized by passage through a $0.22 \mu \mathrm{m}$ filter. This stock solution was added (one part to ten parts medium) to each well of a 96-well tissue culture plate, and the plate was incubated at $37^{\circ} \mathrm{C}$ for $4 \mathrm{~h}$. Viable cells with active mitochondria cleave the tetrazolium ring into a dark blue formazan reaction product. Acid-isopropanol $(400 \mu \mathrm{l}$ of $10 \mathrm{M} \mathrm{HCl}$ in $100 \mathrm{ml}$ isopropanol) was added to all wells and mixed thoroughly to dissolve the dark blue crystals. After a few minutes at room temperature, to ensure that all the crystals were dissolved, the plates were read on a microplate reader at a wavelength of $570-630 \mathrm{~nm}$.

\section{Osteoblast proliferation assay}

Primary osteoblasts were plated at a density of $1 \times 10^{4}$ cells/well of a 96-well plate and cultured for $48 \mathrm{~h}$ in CMRL-1066 medium with and without either 10\% FCS or conditioned media from high density osteoblast 

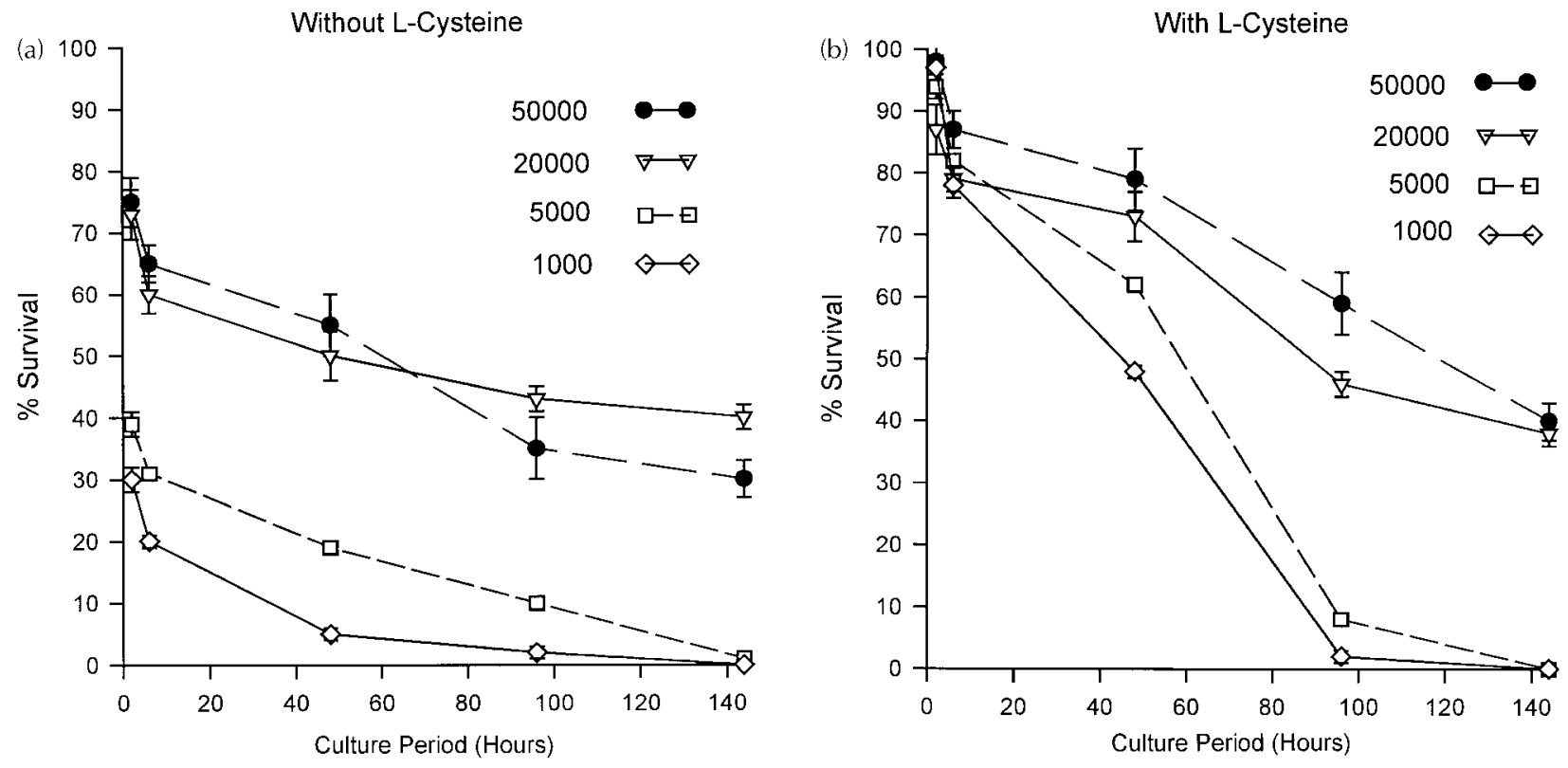

Figure 1 (a) Cell-density dependence of mouse osteoblast survival in culture. Primary mouse osteoblasts were cultured in serum-free CMRL-1066 medium containing thymidine $\left(10^{-3} \mathrm{M}\right)$ but without L-cysteine at various cell densities in 96-well plates, and their viability was assessed by MTT assay after various times. (b) Survival of mouse osteoblasts cultured at high and low cell densities in the presence of cysteine. The osteoblasts were cultured and assessed as in (a) except for the addition of $1 \mathrm{mM}$ L-cysteine to the culture medium. Results are expressed as means \pm S.D.s of four experiments.
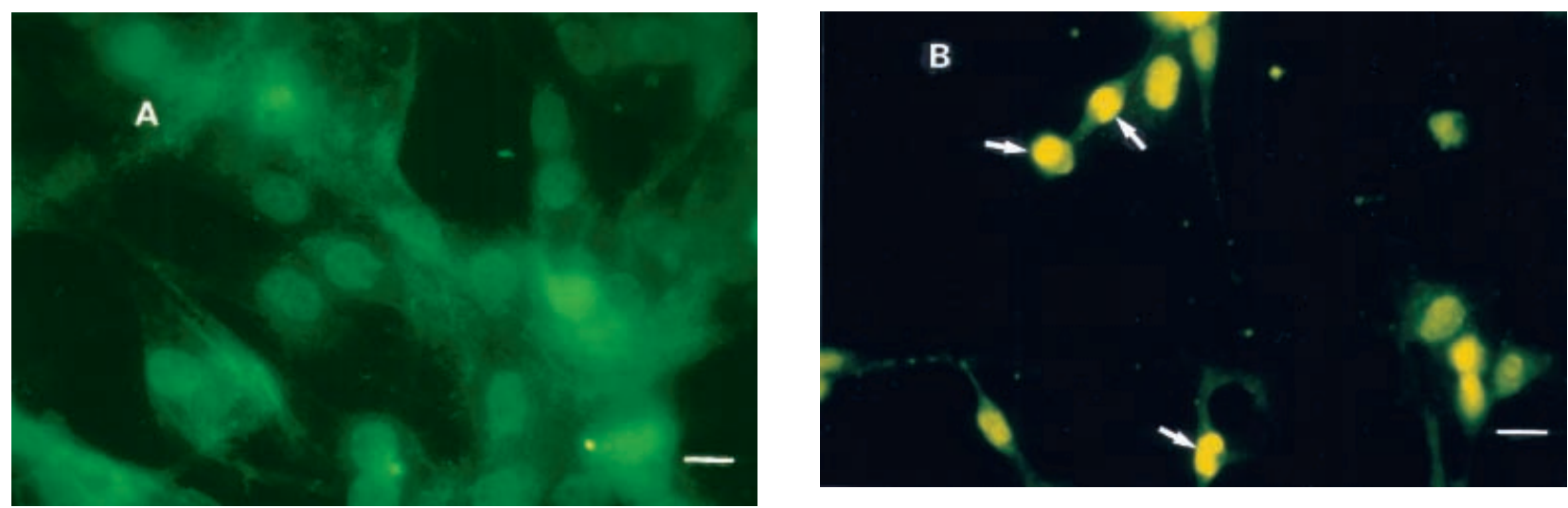

Figure 2 Microphotographs of apoptotic primary mouse osteoblasts in low density cultures, as revealed by TUNEL labelling. Mouse osteoblasts were cultured in CMRL-1066 medium containing thymidine $\left(10^{-3} \mathrm{M}\right)$ and $1 \mathrm{mM}$ cysteine at high density $\left(5 \times 10^{4}\right.$ cells/well) or low density $\left(5 \times 10^{3}\right.$ cells/well). After 4 days, the cells were fixed with $4 \%$ paraformaldehyde, permeabilized by incubation with $0 \cdot 1 \%$ Triton X-100 in 0.1\% sodium citrate for 2 min on ice, and incubated for 30 min with FITC-labelled d-UTP. (A) Typical example of osteoblasts showing negligible DNA fragmentation; (B) cells show intense fluorescence of condensed nuclear chromatin (arrows), indicative of cells in the later stages of apoptosis. Bar $=10 \mu \mathrm{m}$.

cultures in the presence or absence of cold thymidine $\left(10^{-3} \mathrm{M}\right)$. The cells were pulsed for the last $6 \mathrm{~h}$ with $1 \mu \mathrm{Ci}\left[{ }^{3} \mathrm{H}\right]$ cytidine and DNA associated radioactivity was performed at the end of the experiment by fixing the cells with $5 \%$ TCA at $4{ }^{\circ} \mathrm{C}$ for 10 min and washing in PBS and the cells were detached with trypsin-EDTA solution $(0 \cdot 5 \%: 0 \cdot 02 \%)$.

\section{Identification of apoptotic osteoblasts}

(a) TUNEL assay Apoptosis-induced DNA strand breaks were enzymatically labelled by a fluorescein isothiocyanate (FITC) in situ cell-death detection kit (Boehringer Mannheim) based on a terminal deoxynucleotidyl transferase (TdT)-mediated dUTP-nick-end 
labelling (TUNEL) technique which stains individual apoptotic nuclei with green fluorescence (Gavrieli et al. 1992). Briefly, cells were fixed in $4 \%$ paraformaldehyde for $10 \mathrm{~min}$, washed in $10 \mathrm{mM}$ Tris $-\mathrm{HCl}, \mathrm{pH} 8 \cdot 0$, and then permeabilized in $0 \cdot 1 \%$ Triton $\mathrm{X}-100$ in $0 \cdot 1 \mathrm{M}$ sodium citrate for $5 \mathrm{~min}$ on ice. After washing in $10 \mathrm{mM}$ Tris$\mathrm{HCl}, \mathrm{pH} 8.0$ the cells were incubated for $60 \mathrm{~min}$ with TdT and FITC-dUTP at $37^{\circ} \mathrm{C}$. After washing in PBS, the cells were examined in a Leica fluorescence microscope.

(b) DNA fragmentation This was analysed by agarose gel electrophoresis. Primary mouse osteoblasts were cultured in serum-free CMRL-1066 medium. Adherent cells were lysed with $0 \cdot 1 \mathrm{M} \mathrm{NaCl}, 10 \mathrm{mM}$ Tris- $\mathrm{HCl}(\mathrm{pH} 7 \cdot 5)$ and $1 \mathrm{mM}$ EDTA in $0.3 \%$ SDS, and incubated with proteinase $\mathrm{K}(500 \mu \mathrm{g} / \mathrm{ml})$ at $55{ }^{\circ} \mathrm{C}$ for $15 \mathrm{~h}$. Samples were extracted with an equal volume of phenol:chloroform, and the total DNA contained in the aqueous phase was precipitated with a $1 / 10$ volume of sodium acetate $3 \mathrm{M}$, $\mathrm{pH} 6 \cdot 6$, and a 2.5 volume of ethanol at $-80^{\circ} \mathrm{C}$ for $15 \mathrm{~h}$. DNA pellets were obtained by centrifugation $(13000 \boldsymbol{g}$ for $15 \mathrm{~min})$ and resuspended in $50 \mu \mathrm{l}$ of $10 \mathrm{mM}$ Tris- $\mathrm{HCl}$ $(\mathrm{pH} 8.0)$ and $1 \mathrm{mM}$ EDTA. Samples were then treated with $10 \mathrm{U} / \mathrm{ml}$ of DNAse-free RNAse for $1 \mathrm{~h}$ at $37^{\circ} \mathrm{C}$. Electrophoresis was performed on a $2 \%$ agarose gel at $50 \mathrm{~V}$ for $1.5 \mathrm{~h}$ in the presence of $0.5 \mu \mathrm{g} / \mathrm{ml}$ of ethidium bromide.

\section{Statistical analysis}

Data are expressed as the means \pm S.D.s of six cultures per group. Each experiment was performed three times. Differences between control and treatment groups were determined by the Mann-Whitney $U$ test.

\section{Results}

\section{Characterization of murine osteoblasts}

Unstimulated cultures of primary mouse osteoblasts were characterized by histochemical staining for alkaline phosphatase and intracellular accumulation of cAMP in response to PTH. $88 \cdot 2 \pm 2 \cdot 4 \%$ of cells from six separate bone cell preparations were found to be strongly positive for alkaline phosphatase. Treatment of primary mouse osteoblast cultures with PTH $\left(10^{-8} \mathrm{M}\right)$ for $10 \mathrm{~min}$ induced a cAMP level of $10 \cdot 7 \pm 1.8 \mathrm{pmol} / \mathrm{ml}$ compared with a control level of $2 \cdot 34 \mathrm{pmol} / \mathrm{ml}$.

\section{Osteoblast survival in protein-free medium is cell-density dependent}

To study the survival requirements of osteoblasts in culture, osteoblasts prepared from calvaria of 2-day-old mice were cultured at various cell densities in serum-free
CMRL medium containing thymidine $\left(10^{-3} \mathrm{M}\right)$ but no added protein in 96-well plates. Addition of thymidine blocks cell proliferation and therefore permits assessment of factors on cell survival (Murgo et al. 1980). Cell survival was assessed by the MTT assay after various times. Viable cells converted the MTT into a dark blue reaction product, while dead cells remained uncoloured. The survival of osteoblasts was cell-density dependent: when plated at $\geq 2 \times 10^{4}$ cells/well, $30 \%$ of the cells survived for up to $144 \mathrm{~h}$, but when plated at $\leq 5 \times 10^{3}$ cells/well, all the cells had died by $144 \mathrm{~h}$ (Fig. 1a). To confirm our hypothesis that the dead osteoblasts were undergoing apoptosis rather than necrosis, we examined the cells by TUNEL labelling of nuclei with FITC-dUTP and found that a large proportion of the cells had clear-cut staining indicative of chromatin condensation at the nuclear membrane (Fig. 2). The occurrence of apoptosis, as opposed to necrosis, in primary mouse osteoblasts was confirmed by the demonstration of $180 \mathrm{bp}$ DNA fragments, and multimers thereof, in cell extracts (Fig. 3).

\section{Antioxidants prevent osteoblast cell death}

As many inhibitors of apoptosis have antioxidant properties we assessed the effects of a variety of antioxidants on osteoblast survival. The addition of cysteine to the culture medium greatly enhanced the survival of mouse osteoblasts, especially when cultured at $\leq 5 \times 10^{3}$ cells/well, but only for the first $48 \mathrm{~h}$ of culture (Fig. 1b). Thereafter, most of the cells died with the characteristic features of apoptosis. Cystine also promoted survival, but to a lesser extent than cysteine (Table 1). The ability of cysteine to promote survival apparently depended on the intracellular conversion by glutathione synthase to the antioxidant glutathione, as an inhibitor of glutathione synthase, buthionine-sulphoximine (BSO), prevented this effect (Table 1). Glutathione in reduced form (GSH) was as effective as cysteine, while its oxidized form (GSSG) was less effective; neither of their effects were affected by BSO (Table 1).

When superoxide dismutase was added to our culture media, cell viability was not improved whereas catalase clearly protected the osteoblasts. Superoxide dismutase also had no effect in conjunction with catalase (Table 1).

\section{Osteoblasts support one another's survival in culture by secreting survival factors that are not antioxidants}

The finding that osteoblasts survived longer when cultured at high density suggests that the cells in high density cultures promote one another's survival through cell-cell contact survival factors or by secreting survival-promoting factors. Consistent with the latter suggestion, culture medium from high density $\left(10^{5}\right.$ cells/well $)$ osteoblast cultures promoted the survival of low density osteoblast cultures. When osteoblasts were cultured at a cell density 


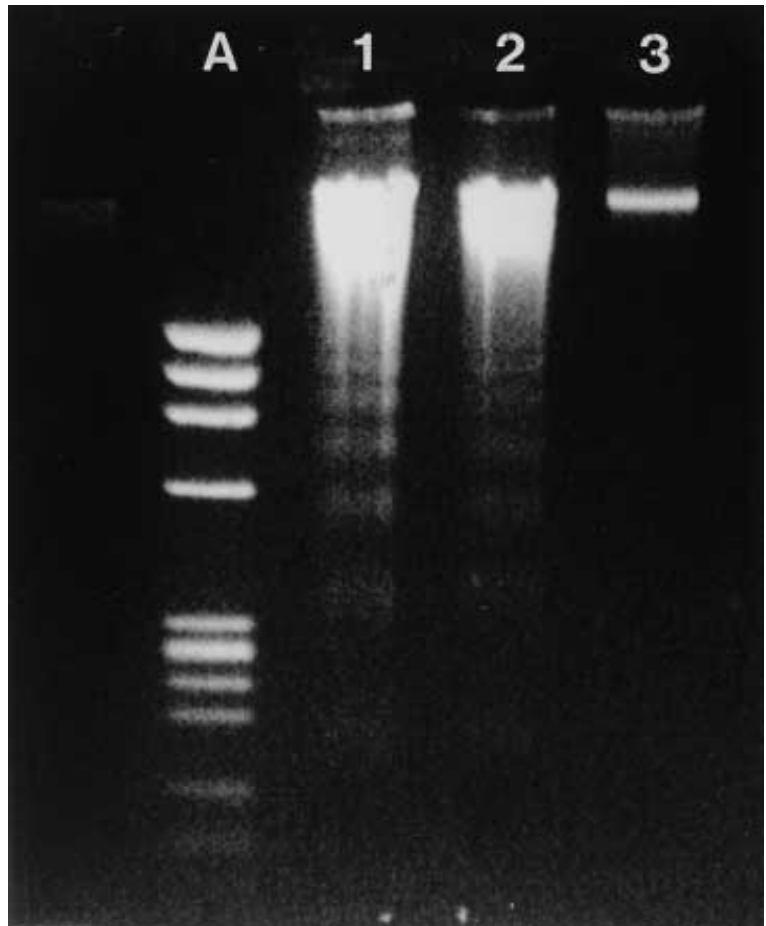

Figure 3 Apoptosis of primary mouse osteoblasts detected by DNA fragmentation. Primary mouse osteoblasts were cultured at a density of 5000 cells per well of 96-well plates in CMRL-1066 medium containing thymidine $\left(10^{-3} \mathrm{M}\right)$, with and without conditioned medium from high density osteoblast cultures for 1 or 2 days. DNA was extracted and $5 \mu \mathrm{g}$ was analysed by electrophoresis on a $\%$ agarose gel. DNA was visualized with ethidium bromide. Lanes 1 and 2, DNA isolated from osteoblasts cultured in the absence of CM from high density cultures after 1 and 2 days respectively. Lane 3, DNA isolated from osteoblasts after 2 days in culture with conditioned medium from high density osteoblast cultures. Lane A, DNA size marker.

of $5 \times 10^{4}$ cells/well in the presence of conditioned medium $63 \pm 4 \%$ of osteoblasts survived after $144 \mathrm{~h}$ in culture compared with a control level of $30 \pm 3 \%$ in the absence of conditioned medium (data not shown). Addition of cysteine to the conditioned medium from high density cultures did not further enhance survival of mouse osteoblasts cultured at $5 \times 10^{4}$ cells/well. Addition of cysteine to the conditioned medium was required to save mouse osteoblasts cultured at $\leq 2 \times 10^{4}$ cells/well (data not shown). A similar effect was seen when conditioned medium from high density human MG63 osteoblast cultures was added to low density mouse osteoblasts (data not shown).

When conditioned medium from high density cultures of either mouse or human osteoblasts was fractionated by ultrafiltration using a membrane with a molecular mass cut-off of $5 \mathrm{kDa}$, the survival-promoting activity was recovered in the concentrate and not in the filtrate. When cultured at a cell density of $5 \times 10^{3}$ in the presence of
Table 1 Assessment of the effects of antioxidants on the survival of osteoblasts cultured at low density

\begin{tabular}{llll} 
& Conc. $(\mathrm{M})$ & & \% Survival \\
\cline { 2 - 2 } $\begin{array}{ll}\text { Treatment } \\
\text { Control }\end{array}$ & & \\
BSO & $2 \times 10^{-4}$ & & $30 \pm 1 \cdot 6$ \\
Cysteine & $10^{-3}$ & & $30 \pm 2 \cdot 2$ \\
Cystine & $10^{-3}$ & & $52 \pm 1 \cdot 5^{* *}$ \\
Cysteine+BSO & & $34 \pm 2 \cdot 1^{* *}$ \\
Cystine+BSO & & $27 \pm 2 \cdot 6$ \\
GSH & $10^{-3}$ & $60 \pm 2 \cdot 4^{* *}$ \\
GSH+BSO & & $57 \pm 1 \cdot 7^{* *}$ \\
GSSG & $10^{-3}$ & $40 \pm 1 \cdot 1^{*}$ \\
GSSG+BSO & & $38 \pm 1 \cdot 0^{*}$ \\
SOD & $50 U$ & $32 \pm 2 \cdot 0$ \\
Catalase & $50 U$ & $56 \pm 2 \cdot 7^{* *}$ \\
SOD+Catalase & & $58 \pm 2 \cdot 1^{* *}$ \\
\cline { 2 - 3 } & &
\end{tabular}

Mouse osteoblasts were cultured for $48 \mathrm{~h}$ in CMRL-1066 medium at $5 \times 10^{3}$ cells per well, and their viability was assessed by MTT assay. BSO, buthionine-sulphoximine; GSH, reduced glutathione; GSSG, oxidized glutathione; SOD, superoxide dismutase. The results are the means \pm S.E.M.S of quadruplicate cultures. ${ }^{*} P<0 \cdot 05,{ }^{*} P<01$ significantly different from controls.

Table 2 Assessment of the effects of cold thymidine $\left(10^{-3} \mathrm{M}\right)$ on osteoblast proliferation in the presence/absence of either $2 \%$ FCS or conditioned medium from high density osteoblast cultures

\begin{tabular}{|c|c|c|}
\hline & $\begin{array}{l}\text { Cold thymidine } \\
(+/-)\end{array}$ & d.p.m. \\
\hline \multicolumn{3}{|c|}{ Treatment } \\
\hline Control & + & $2056 \pm 234$ \\
\hline Control & - & $1975 \pm 216$ \\
\hline $2 \%$ FCS & + & $2213 \pm 222$ \\
\hline $2 \%$ FCS & - & $14324 \pm 654$ \\
\hline $\mathrm{CM}$ & + & $2351 \pm 176$ \\
\hline $\mathrm{CM}$ & - & $9865 \pm 543$ \\
\hline
\end{tabular}

Primary mouse osteoblasts prelabelled with $\left[{ }^{3} \mathrm{H}\right]$ cytidine were cultured at a density of 10000 cells/well of a 96-well plate in CMRL medium with and without cold thymidine for $48 \mathrm{~h}$. CM: conditioned medium from high density osteoblast cultures. The results are the means \pm S.E.M.S of quadruplicate cultures.

concentrate $83 \pm 5 \%$ of osteoblasts survived after $48 \mathrm{~h}$ and $47 \pm 4 \%$ after $144 \mathrm{~h}$ compared with a control level of $48 \pm 3 \%$ for osteoblasts cultured after $48 \mathrm{~h}$ and $8 \pm 1 \%$ after $144 \mathrm{~h}$ in the absence of conditioned medium (data not shown). However, when osteoblasts were cultured in the presence of the filtrate only $56 \pm 3 \%$ survived after $48 \mathrm{~h}$ and $13 \pm 2 \%$ survival was observed after $144 \mathrm{~h}$. This suggested that one or more osteoblast-derived growth factors was responsible for promoting osteoblast survival.

Labelling osteoblast DNA with $\left[{ }^{3} \mathrm{H}\right]$ cytidine confirmed that cold thymidine effectively blocked the effects of FCS and conditioned medium from high density cultures on osteoblast proliferation (Table 2). 
Table 3 Effects of neutralizing antibodies to growth factors on the survival-promoting effects of osteoblast conditioned medium on murine osteoblast cells

\section{$\%$ Survival of osteoblasts}

\begin{tabular}{|c|c|c|}
\hline $\begin{array}{l}\text { Low density } \\
\text { cultures }\end{array}$ & $\begin{array}{l}\text { Low density } \\
\text { cultures + } \\
\text { conditioned } \\
\text { medium }\end{array}$ & $\begin{array}{l}\text { High density } \\
\text { MG63 cultures }\end{array}$ \\
\hline $8 \pm 3$ & $51 \pm 6$ & $44 \pm 5$ \\
\hline $12 \pm 4$ & $12 \pm 4^{* *}$ & $14 \pm 2^{* *}$ \\
\hline $9 \pm 3$ & $14 \pm 3^{* *}$ & $9 \pm 2^{* *}$ \\
\hline $14 \pm 4$ & $52 \pm 6$ & $46 \pm 5$ \\
\hline $7 \pm 3$ & $54 \pm 5$ & $51 \pm 4$ \\
\hline
\end{tabular}

Murine osteoblasts were cultured in 96-well plates at low cell density $\left(5 \times 10^{3}\right.$ cells/well) and MG63 osteoblasts were cultured at high cell density $\left(5 \times 10^{4}\right.$ cells/density) for 2 days. Conditioned medium from high density MG63 cultures was added to the low density cultures as indicated. Human polyclonal antibodies to FGF, IGF-I and IGF-II were added at a final concentration of $2 \mu \mathrm{g} / \mathrm{ml}$ and to PDGF at $5 \mu \mathrm{g} / \mathrm{ml}$. The results are the means \pm S.E.M.S of quadruplicate cultures. ${ }^{*} P<00 \cdot 01$ significantly different from the control.

Effects of neutralizing antibodies to growth factors on osteoblast survival

To determine which particular growth factors might be responsible for promoting osteoblast survival we assessed the effects of neutralizing antibodies to those growth factors that are produced by osteoblasts. We found that antibodies to IGF-I and -II were capable of preventing the survival-promoting effects of conditioned medium on low density osteoblast cultures whilst antibodies to PDGF and bFGF were without effect and did not augment the inhibitory activity of the IGF antibodies (Table 3). When the various antibodies were added to high density MG63 osteoblast cultures in the absence of conditioned medium, a similar effect was observed (Table 3).

\section{Discussion}

Our studies demonstrate that osteoblasts do not require signals from other cell types to survive if cultured at high cell density in the absence of serum, exogenous proteins or non-protein molecules. This is similar to survival characteristics of both chondrocytes and lens epithelial cells (Tschan et al. 1990, Ishizaki et al. 1993). Our studies also show that osteoblasts require assistance from other osteoblasts to survive in culture: the cells die rapidly when cultured at low cell density, but can be saved by conditioned medium from high density osteoblast cultures. The apparent rapid cell death prominent in cells cultured at a density of $\leq 5 \times 10^{3}$ cells per well within the first $3 \mathrm{~h}$ of switching to serum-free medium may be due to a lack of adhesion resulting from a lack of cell-cell contact survival factors. We deomonstrate that the deaths involve activation of an endogenous endonuclease as shown by DNA laddering, a characteristic feature of apoptosis (Wyllie et al. 1980), suggesting that the cells die by active PCD.

The survival of a given cell may be determined by its balance of reactive oxygen intermediates (ROI) and antioxidants. Our demonstration that a variety of antioxidants that scavenge or detoxify ROIs suggests that the latter may be responsible for mediating osteoblast death in the low density cultures.

Since sulphydryl reagents can act as oxygen radical scavengers (Cadenas 1989), these observations suggested such radicals might be a possible cause of the observed cytotoxicity. Oxygen radicals arise from molecular oxygen by one-electron transfer reactions. For example, $\mathrm{O}_{2}{ }^{-\bullet}$ and $\mathrm{OH} \cdot$ can be formed in the presence of $\mathrm{Fe}^{2+}$ according to:

$$
\begin{aligned}
& \mathrm{O}_{2}+\mathrm{Fe}^{2+} \rightarrow \mathrm{O}_{2}^{-\bullet}+\mathrm{Fe}^{3+} \\
& 2 \mathrm{O}_{2}^{-\bullet}+2 \mathrm{H}^{+} \rightarrow \mathrm{O}_{2}+\mathrm{H}_{2} \mathrm{O}_{2} \\
& \mathrm{H}_{2} \mathrm{O}_{2}+\mathrm{Fe}^{2+} \rightarrow \mathrm{OH}+\mathrm{OH}^{2}+\mathrm{Fe}^{3+}
\end{aligned}
$$

Toxic oxygen-derived compounds can be eliminated enzymatically. $\mathrm{O}_{2}{ }^{-}$is decomposed by superoxide dismutase, and catalase degrades $\mathrm{H}_{2} \mathrm{O}_{2}$ to oxygen and water, thus also preventing the production of $\mathrm{OH}^{-}$(formula 3 ). Both of these enzymes are known to protect cells from oxygen toxicity (Cadenas 1989). Our results show that oxygen toxicity caused the loss of viable cells in serum-free osteoblast culture. The findings also emphasize the importance of $\mathrm{H}_{2} \mathrm{O}_{2}$ or $\mathrm{OH}^{\bullet}$, rather than $\mathrm{O}_{2}{ }^{-}$.

Although we found that antioxidants are important for the survival of osteoblasts in low density cultures $\left(\leq 5 \times 10^{3}\right.$ cells/well), they are not enough: extracellular signalling molecules also seem to be required. This is suggested by our findings that (a) the survival-promoting activity in the conditioned medium from high density osteoblast cultures collaborates with antioxidants such as cysteine and is associated with molecules that are larger than $5 \mathrm{kDa}$, and (b), this activity is prevented by antibodies to known growth factors.

While conditioned medium from high density osteoblast cultures does not require antioxidants to promote the survival of either mouse or human osteoblasts cultured at $5 \times 10^{4}$ cells/well, it does require antioxidants to promote the survival of osteoblasts cultured at $\leq 5 \times 10^{3}$ cells/well. We conclude that osteoblasts, like chondrocytes and many other cells, require signals from their neighbours in order to avoid PCD, at least in culture. Furthermore, these signals do not function solely as antioxidants, and osteoblasts themselves can secrete such signals. However, the evidence from this study showing that conditioned medium from high density osteoblast cultures was unable to achieve a $100 \%$ osteoblast survival rate, suggests that other factors, possibly cell-to-cell contact factors, play a role in promoting the survival of osteoblasts cultured at high cell densities. 
Of the neutralizing antibodies to growth factors that we tested, both the IGF-I and IGF-II antibodies prevented the survival-promoting activity of osteoblast conditioned medium. Osteoblasts have been shown to make both these growth factors (McCarthy et al. 1989) and we have previously shown that IGF-I and IGF-II stimulate osteoblast survival in vitro via an interaction with type-I IGF receptors (Hill et al. 1997); it seems likely that these growth factors may promote osteoblast survival in vivo. Whilst these growth factors stimulate osteoblast proliferation (McCarthy et al. 1989, Ernst \& Rodan 1990), we were able to differentiate between their effects on survival and proliferation by incorporating cold thymidine into the culture medium which effectively blocked the proliferative effects of the conditioned medium. Although bFGF, transforming growth factor- $\beta$ (TGF $\beta$ ), PDGF, IGF-I and IGF-II are all present in the bloodstream, it is apparent that the paracrine biosynthesis of growth factors is more important in the modulation of cellular activity (Holly \& Wass 1989). The IGFs are probably two of the most important regulators of bone mass because they are synthesized by bone cells, and are present in substantial concentrations in bone tissue (Ernst \& Rodan 1990). It seems likely that growth factors released from the extracellular matrix and neighbouring cells are responsible for promoting the survival of osteoblasts in bone as they do in vitro. The IGFs have previously been shown to be important survival factors during normal tissue development of other cell types such as Schwann cells (Delaney et al. 1999) and also in the prevention of cytokine-mediated cell death in pancreatic islets (Hill et al. 1999). The IGFs have also been shown to prevent apoptosis in many tumour cell lines. It has been demonstrated that IGF-I is the most important growth factor present in serum that prevents apoptosis in neuroblastoma cells (Van Golen \& Feldman 2000) and this is associated with regulation of the levels of the anti-apoptotic proteins $\mathrm{Bcl}-2$ and $\mathrm{Bcl}-\mathrm{X}_{\mathrm{L}}$. IGF-I also protects colon cancer cells from death factorinduced apoptosis (Remacle-Bonnet et al. 2000). In contrast to the survival-promoting effects of IGF-I reported here, it has been demonstrated that stimulation of human osteoblasts with IGF-I induces expression of Fas and subsequently increases their susceptibility to Fas-mediated apoptosis when co-cultured with $\mathrm{FasL}^{+}$cells (Kawakami et al. 1998). It remains to be seen whether IGF-I increases susceptibility to Fas-mediated apoptosis in murine osteoblasts.

The isolation procedure used in this study will yield osteoblasts at different stages of differentiation from osteoprogenitor through to mature osteoblasts. A significant proportion of these cells stain strongly for alkaline phosphatase, suggesting they are of the pre-osteoblast/ osteoblast stage of differentiation. Although it is not certain whether osteoprogenitors express IGF-I or IGF-I receptors, evidence suggests that genes for regulatory proteins such as fibroblast growth factor receptor-I are modulated during progression from late osteoprogenitor to preosteoblast and osteoblast stages (Aubin 1998). Therefore, in our culture system these stages would be responsive to the survival-promoting effects of IGF-I.

Although interleukin-6 (IL-6) and transforming growth factor- $\beta$ (TGF- $\beta$ ) have recently been shown to prevent tumour necrosis factor- $\alpha$ (TNF $\alpha$ )-mediated apoptosis in murine MC3T3-E1 osteoblasts in vitro (Jilka et al. 1998), our previous studies have shown that neither of these cytokines influence osteoblast survival (Hill et al. 1997). Further studies will be necessary to clarify the role of IL-6 and TGF- $\beta$ in osteoblast survival under differing conditions since these cytokines have been found to promote apoptosis in other cell types. Although we found no inhibitory activity with either bFGF or PDGF neutralizing antibodies this does not exclude a role for the involvement of these growth factors in vivo. There are an increasing number of examples where several distinct extracellular signalling molecules have been shown to collaborate to promote cell survival in culture (Barres et al. 1993), presumably reflecting the advantages of combinatorial control.

Although we did not assess whether other cells within the bone microenvironment can promote the survival of osteoblasts, it has previously been shown that lens epithelial cells can promote chondrocyte survival and vice versa (Ishizaki et al. 1994). One theoretical advantage of having cells depend on signals from their neighbours for survival is that any cell that ends up in an abnormal location would fail to receive the survival signals it requires and would consequently die; because cells seem to require a combination of signals for sustained survival, at least in culture, a relatively small selection of signalling molecules used in different combinations could specifically control the survival of many distinct cell types.

Interestingly, osteoblast apoptosis has been shown to occur in vivo with a frequency of $\sim 0.6 \%$ (Jilka et al. 1998) and it has been concluded that only about 15\% of terminally differentiated osteoblasts survive to become osteocytes in vivo (Parfitt 1990), although what activates the death program in these cells remains unknown. An explanation may involve the loss of expression of type-I IGF receptors by terminally differentiated osteoblasts similar to the loss of expression of bFGF receptors by hypertrophic chondrocytes (Iwamoto et al. 1991).

Osteoblast apoptosis has also been shown to be important in the pathogenesis of certain metabolic bone diseases. Studies have shown that exposure to high doses of glucocorticoids such as dexamethasone increase apoptosis of mature osteoblasts and osteocytes resulting in glucocorticoid-induced osteoporosis (Weinstein et al. 1998). Interestingly, it has been shown that glucocorticoids decrease levels of mRNA and polypeptide for IGF-I (Delaney \& Canalis 1995) and thus some of the effects of glucocorticoid excess may be mediated by decreased levels of IGF-I. Osteoblast apoptosis may also be important in postmenopausal osteoporosis since it has been shown that 
oestrogen inhibits osteocyte and osteoblast apoptosis (Manolagas et al. 1999).

Future studies will be directed towards elucidating the role of cell-cell contact in osteoblast survival.

\section{References}

Aubin JE 1998 Advances in the osteoblast lineage. Biochemistry and Cell Biology 76 899-910.

Barres BA, Hart IK, Coles HS, Burne JF, Voyvodic JT, Richardson WD \& Raff MC 1992 Cell death and control of cell survival in the oligodendrocyte lineage. Cell 70 31-46.

Barres BA, Schmid R, Sendtner M, Thoen H \& Raff MC 1993 Multiple extracellular signals are required for long-term oligodendrocyte survival. Development 118 283-295.

Baserga R 1985 The Biology of Cell Reproduction. Cambridge, MA: Harvard University Press.

Biggers JD, Whitten WK \& Whittingham DG 1971 The culture of mouse embryo in vitro. In Methods in Mammalian Embryology, pp 86-116. Ed JC Daniel. San Francisco, CA: Freeman Publications.

Cadenas E 1989 Biochemistry of oxygen toxicity. Annual Review of Biochemistry $\mathbf{5 8}$ 79-110.

Delaney AM \& Canalis E 1995 Transcriptional repression of insulinlike growth factor I by glucocorticoids in rat bone cells. Endocrinology 136 4776-4781.

Delaney CL, Cheng HL \& Feldman EL 1999 Insulin-like growth factor-I prevents caspase-mediated apoptosis in Schwann cells. Journal of Neurobiology 41 540-548.

Ernst M \& Rodan GA 1990 Increased activity of insulin-like growth factor (IGF) in osteoblastic cells in the presence of growth hormone $(\mathrm{GH})$ : positive correlation in the presence of the GH-induced IGF binding. Endocrinology 1127 807-814.

Fawcett DW 1986 A Textbook of Histology, edn 11. Philadelphia, PA: WB Saunders.

Gavrieli Y, Sherman Y \& Ben Sasson SA 1992 Identification of programmed cell death in situ via specific labelling of nuclear DNA fragmentation. Journal of Cell Biology 119 493-501.

Gohel A, McCarthy M \& Gronowicz G 1999 Estrogen prevents glucocorticoid-induced apoptosis in osteoblasts in vivo and in vitro. Endocrinology 140 5339-5347.

Goss RJ 1978 The Physiology of Growth. New York: Academic Press.

Heath JK, Atkinson S, Meikle MC \& Reynolds JJ 1984 Mouse osteoblasts synthesize collagenase in response to bone resorbing agents. Biochimica et Biophysica Acta 802 151-154.

Hill DJ, Petrik J, Arany E, McDonald TJ \& Delovitch TL 1999 Insulin-like growth factors prevent cytokine-mediated cell death in isolated islets of Langerhans from pre-diabetic non-obese diabetic mice. Journal of Endocrinology 161 153-165.

Hill PA, Tumber A \& Meikle MC 1997 Multiple extracellular signals promote osteoblast survival and apoptosis. Endocrinology 138 3849-3858.

Holly JMP \& Wass JAH 1989 Insulin-like growth factors: autocrine, paracrine, or endocrine? New perspectives of the somatomedin hypothesis in the light of recent developments. Journal of Endocrinology 122 611-618.

Ishizaki Y, Voyvodic JT, Burne JF \& Raff MC 1993 Control of lens epithelial cell survival. Journal of Cell Biology 121 899-908.

Ishizaki Y, Burne JF \& Raff MC 1994 Autocrine signals enable chondrocytes to survive in culture. Journal of Cell Biology 126 1069-1077.

Iwamoto M, Shimazu A, Nakashima K, Suzuki F \& Kato Y 1991 Reduction in basic fibroblast growth factor receptor is coupled with terminal differentiation of chondrocytes. Journal of Biological Chemistry 266 461-467.
Jilka RL, Weinstein RS, Bellido T, Parfitt AM \& Manolagas SC 1998 Osteoblast programmed cell death (apoptosis): modulation by growth factors and cytokines. Journal of Bone and Mineral Research 13 793-802.

Kawakami A, Nakashima T, Tsuboi M, Urayama S, Matsuoka N, Ida H, Kawabe Y, Sakai H, Migita K, Aoyagi T, Nakashima M, Maeda K \& Eguchi K 1998 Insulin-like growth factor I stimulates proliferation and fas-mediated apoptosis of human osteoblasts. Biochemical and Biophysical Research Communications 247 46-51.

Levi-Montalcini R 1987 The nerve growth factor: 35 years later. EMBO Journal 6 1145-1154.

Manolagas SC, Weinstein RS, Bellido T \& Bodenner DL 1999 Opposite effects of estrogen on the life span of osteoblasts/ osteocytes versus osteoclasts in vivo: an explanation of the imbalance between formation and resorption in estrogen efficiency. Journal of Bone and Mineral Research 14 S169.

McCarthy TL, Centrella M \& Canalis E 1989 Parathyroid hormone enhances the transcript and the polypeptide levels of insulin-like growth factor-I in osteoblast enriched cultures from fetal rat bone. Endocrinology 124 1247-1253.

Mosmann T 1983 Rapid colorimetric assay for cellular growth and survival: application to proliferation and cytotoxicity assays. Journal of Immunological Methods 65 55-63.

Murgo AJ, Fried J, Burchenal D, Vale KL, Strife A, Woodcock T, Young CW \& Clarkson BD 1980 Effects of thymidine and thymidine plus 5 -fluorouracil on the growth kinetics of a human lymphoid cell line. Cancer Research 40 1543-1549.

Parfitt AM 1990 Bone forming cells in clinical conditions. In Bone, Vol 1: The Osteoblast and Osteocyte, pp 351-429. Ed BK Hall. Boca Raton, FL: Telford Press and CRC Press.

Plotkin LI, Weinstein RS, Parfitt AM, Roberson PK, Manolagas SC \& Bellido T 1999 Prevention of osteocyte and osteoblast apoptosis by bisphosphonates and calcitonin. Journal of Clinical Investigation $1041363-1374$.

Raff MC 1992 Social controls on cell survival and cell death. Nature 356 397-400.

Remacle-Bonnet MM, Garrouste FL, Heller S, Andre F, Marvaldi JL \& Pommier GJ 2000 Insulin-like growth factor I protects colon cancer cells from death factor-induced apoptosis by potentiating tumour necrosis factor alpha-induced mitogen-activated protein kinase and nuclear factor kappaB signalling pathways. Cancer Research $602007-2017$.

Tschan T, Hoerler I, Houze Y, Winterhalter KH, Richter C \& Bruckner P 1990 Resting chondrocytes in culture survive without growth factors, but are sensitive to toxic oxygen metabolites. Journal of Cell Biology 111 257-260.

Van Golen CM \& Feldman EL 2000 Insulin-like growth factor I is the key growth factor in serum that protects neuroblastoma cells from hyperosmotic-induced apoptosis. Journal of Cellular Physiology $18224-32$.

Weinstein RS, Jilka RL, Parfitt AM \& Manolagas SC 1998 Inhibition of osteoblastogenesis and promotion of apoptosis of osteoblasts and osteocytes by glucocorticoids. Journal of Clinical Investigation 102 274-282.

Williams GT, Smith CA, Spooner E, Dexter TM \& Taylor DR 1990 haemopoietic colony stimulating factors promote cell survival by suppressing apoptosis. Nature 343 76-78.

Wyllie AH 1980 Glucocorticoid-induced thymocyte apoptosis is associated with endogenous endonuclease activation. Nature 284 555.

Wyllie AH, Kerr JFR \& Currie AR 1980 Cell death: the significance of apoptosis. International Review of Cytology 68 251-307.

Received 10 May 2000

Accepted 8 August 2000 